it is hoped to award five Fellowships each year of an approximate value of $£ 900-£ 1,200$ each. Further particulars and forms of application can be obtained from the Secretary, Mond Nickel Fellowships Committee, 4 Grosvenor Gardens, London, S.W.1. Completed forms must be returned not later than June 1, 1959.

\section{The Creole Foundation Prize}

The Creole Foundation, created by the Creole Petroleum Corporation-which is affiliated to the Standard Oil Company of New Jersey, and operates in Venezuela - with the object of encouraging the development of university, technical and industrial education and of scientific research in general, is offering a prize to be known as the Creole Foundation Prize. This will consist of 10,000 U.S. dollars and a diploma to be awarded to the author or authors of a work, selected through a competition, on any aspect of Venezuela in the fields of the natural, physical or social sciences. The prize will be given every two years in Caracas, beginning on October 17, 1960, the anniversary date of the creation of the Foundation; travelling and living expenses to Caracas will also be paid. Works to be submitted for the competition, which may be of any length and must either be written in Spanish, English, French, German, Italian or Portuguese or be accompanied by an adequate summary in one of those languages, must be received before December 31 in the year immediately preceding that in which the prize is to be awarded, at Premio Fundacion Creole, Apartado 889, Caracas, Venezuela, from which further information can be obtained.

\section{University News :}

London

THE title of professor of physiology in the University of London has been conferred on Dr. J. A. B. Gray in respect of his post at University College. The title of reader in physics in the University has been conferred on Dr. R. L. F. Boyd in respect of his post at University College ; and that of reader in political economy in the Univorsity has been conferred on Mr. W. J. Corlett in respect of his post at University College. Dr. M. J. Seaton, lecturer at University College, has been appointed to the University readership in physics tenable at that College.

\section{Announcements}

Sir George R. Edwards, managing director of Vickers-Armstrongs (Aircraft), Ltd, and immediate past president of the Royal Aeronautical Society, has been made an Honorary Fellow of the American Institute of the Aeronautical Sciences. Dr. A. M. Ballantyne, secretary of the Royal Aeronautical Society, has been elected a Fellow of the Institute of the Aeronautical Sciences.

THe Swiney Prize of the Royal Society of Arts for the best published work on medical jurisprudence has been awarded to Dr. Keith Simpson, reader in forensic medicine to the University of London at Guy's Hospital Medical School, for his book, "Forensic Medicine" (third edition). The Prize, which consists of $£ 100$ and a silver cup of the same value, is awarded on every fifth anniversary of Dr. George Swiney's death in 1844 for the best published work alternately on medical and general jurisprudence. The award is made by a joint committee of the Royal Society of Arts and the Royal College of Physicians.
ON his resignation from the post of assistant secretary of the Royal Meteorological Society, Mr. M. E. Shoenberg has been made a life-member of the Society. His successor at the Society is Mr. R. H. Lovinson.

Prof. A. N. Duckham has been appointed chairman of the Milk and Milk Products Technical Advisory Committee of the Ministry of Agriculture, Fisheries and Food in succession to Prof. H. D. Kay.

Griffin and George (Research and DevelopMENT), LTD., has been formed by the Griffin and George Group to conduct research into, and the development of, new and improved scientific instruments and apparatus for laboratory use and process control. Dr. A. J. P. Martin, well known for his work on partition chromatography, acknowledged by the award in 1952 of the Nobel Prize for chemistry (jointly with Dr. R. Synge), has been appointed research director.

THE Ergonomics Research Society is holding a symposium on "Ergonomics: its Place in Industry" in Oxford during April 6-9. The symposium is intended to provide an opportunity for reviewing progress in the field of ergonomics research and application and for considering future developments in this field. Further information can be obtained from Dr. S. Griew, Department of Psychology, 22 Berkeley Square, Bristol 2.

The Institute of Physics is arranging a one-day symposium entitled "Current Developments in the Production of High Vacua", to be held in London on April 17. There will be three sessions devoted to chemical and ionic pumping in kinetic vacuum systems; problems in the production of high vacua in large equipment; and analysis of residual gases in kinetic vacuum systems. Abstracts (but not preprints) will be circulated before the symposium, the proceedings of which will not be published in full. All inquiries should be addressed to the Secretary, Institute of Physics, 47 Belgrave Square, London, S.W.1.

THE University of Liverpool is arranging a special Conference on Mathematics, to be held at Derby Hall, Liverpool, during April 5-11. The Conference is intended to provide an opportunity for teachers of mathematics in grammar sehools, technical colleges and universities to meet mathematicians employed in industry, government establishments and research organizations, and learn something at first hand of mathematies in action. Prof. Louis Rosenhead will be chairman of the Conference, which will be mainly residential, but arrangements are being made to enable local teachers to attend on a non-residential basis. Inquiries should be addressed to the Director of Extra-Mural Studies, The University, Liverpool.

THE Proceedings of the International Congress on Radiation Research, held in Burlington, Vermont, during August 11-15, will soon be published by the Academic Press, Inc. The volume will be Supplement 1 of the journal Radiation Research, and has been edited by Douglas E. Smith, Argonne National Laboratory, Lemont, Illinois.

Erratum. In the communication entitled "Population Differentiation within Plant Species in Response to Soil Factors" in Nature of January 10, p. 129, the names against the curves in Fig. 1 should be interchanged. 